УДК 33.336.1:352

Шульженко I.B., к.е.н., доцент

Shulzhenko I.Candidate of Economic Sciences, Associate Professor https://orcid.org/0000-0003-3608-4157

Дорошенко М.В., Сосніцький А.В., магістранти спеціальності «Менеджмент» Doroshenko M., Sosnitskyi A., Master's degree in Management

\title{
ОСОБЛИВОСТІ МОТИВАЦЇ̈ В ПРОЦЕСІ КОМАНДНОЇ РОБОТИ ПЕРСОНАЛУ ОРГАНІЗАЦІї
}

\author{
Полтавська державний аграрний університет
}

\begin{abstract}
У статті досліджуються особливості мотивації персоналу в процесі командної роботи, зокрема шляхом управління конфліктами. Механізм мотивації працівників сучасного підприємства повинен базуватися на основних положеннях соціально орієнтованого управління. 3 метою впровадження основних положень соціально-орієнтованого менеджменту в повсякденну діяльність організацій доцільно створити команди, які дозволять оперативно реагувати на динамічні зміни у зовнішньому та внутрішньому середовищі.
\end{abstract}

Командна робота $є$ важливою складовою процесу управління, що дозволяє покращити та виправити існуючі відхилення від бажаного стану в системі мотивації працівників організації. Зрозуміло, що це надзвичайно важливо, зокрема для оптимізації управлінського впливу на працівників.

Для цього необхідно розробити відповідний механізм, тобто систему цілей, вимог, принципів, методів та форм мотивації членів команди. У цій системі кожен елемент взаємопов'язаний і залежить від інших.

Основним показником налагодженої взаємодії команди є підвищення ефективності організації. Ефективна робота в команді - це здатність менеджера знаходити оптимальні способи взаємодії у багатьох питаннях, включаючи управління конфліктами, які виникають у процесі роботи в команді.

Навики управління конфліктами грунтуються на глибоких знаннях менеджера про природу, характеристики, технологію та особливості відповідних інструментів. Крім того, конфлікти та їх вирішення мають залишатися професійними і не переходити до особистих звинувачень та обговорень. Цілі та наслідки формування команди є одночасно передумовами запобігання конфліктам в організації та методом управління ними.

Згуртованість та послідовність взаємодії команди 3 великою ймовірністю вплине на систему мотивації та діяльність організації в довгостроковій перспективі.

Ключові слова: команда, командна робота, організація, сочіально-орієнтоване управління, мотивація, конфлікт, командна взаємодія, дисфункціональні конфлікти, мотиваційні процеси.

\section{PECULIARITIES OF PERSONNEL MOTIVATION IN THE PROCESS OF TEAM PERSONNEL ORGANIZATION}

\section{Poltava State Agrarian University}

The article examines the features of staff motivation in the process of teamwork, in particular through conflict management. The mechanism of motivation of employees of a modern enterprise should be based on the basic provisions of socially oriented management. In order to implement the basic provisions of socially-oriented management in the daily activities of organizations, it is advisable to create teams that allow you to respond quickly to dynamic changes in the external and internal environment.

Teamwork is an important component of the management process, which allows to improve and correct existing deviations from the desired state in the system of motivation of employees of the organization. It is clear that this is extremely important, in particular for optimizing managerial influences on employees.

To do this, it is necessary to develop an appropriate mechanism, ie a system of goals, requirements, principles, methods and forms of motivation of team members. In this system, each element is interconnected and depends on the others.

The main indicator of well-established team interaction is to increase the effectiveness of the organization. Effective teamwork is the manager's ability to find optimal ways to interact in many issues, including managing conflicts that occur in the teamwork process.

Conflict management skills are based on the manager's deep knowledge of the nature, characteristics, 
technology and features of the relevant tools. In addition, conflicts and their resolution should remain professional and not move to personal accusations and discussions. The goals and consequences of team building are both prerequisites for conflict prevention in the organization and a method of managing them.

Cohesion and coherence of team interaction with a high probability will affect the system of motivation and activities of the organization in the long run.

Key words: team, team work, organization, socially-oriented management, motivation, conflict, team interaction, dysfunctional conflicts, motivational processes.

Постановка проблеми у загальному вигляді i iï зв'язок 3 важливими науковими та практичними завданнями. Форми і методи мотивації працівників постійно змінюються та удосконалюються в залежності від сукупності зовнішніх та внутрішніх чинників. Вагомим напрямом тут є злагоджена командна робота, яка створює відповідний мікроклімат в колективі і дозволяє уникнути дисфункціональних конфліктів.

Робота в команді стимулює кожного працівника до досягнення як особистих, так i загальноорганізаційних цілей. Тому проблема удосконалення мотивації в процесі командної взаємодії у соціально-орієнтованому управління $є$ актуальною.

Аналіз останніх досліджень, у яких започатковано вирішення проблеми. Висвітленням загальних питань командної роботи займались дуже багато як закордонних, так і вітчизняних вчених. Зокрема, загальними проблемам командної роботи присвячені роботи таких закордонних вчених, як: Дж.Р. Кемзенбер, К. ЛевісМакКлеар, Д.К. Сміт, М. Тейлор, Т. Базаров, І. Рибкін, Т. Пиркова, О. Голентовська [5], В. Москаленко [6], Р. Муха [4] та інші. Теоретичним та практичним аспектам аналізу причин виникнення організаційних конфліктів в організаціях присвячена значна кількість робіт учених, таких як Акофф Р., Эмері Ф., Голобородько Г.П. [6], Криса О.Й. [7], Новікова Н. [8] та ін.

Питання мотивування діяльності працівників досліджувались та грунтовно описані у працях вітчизняних та зарубіжних науковців, серед яких: М. ТуганБарановський, А. Колот, В. Климчук (2), В. Джеймс, Ю.І Палеха, А. Петиченко [10], А.М. Полиця [1], І. М. Грінько [9], І.Б. Швець [1], І. М. Хоменко [9] та інші. У своїх працях дослідниками описані основні категорії мотиваційного процесу, сформовано основні методи мотивації, визначені чинники результативності мотивування працівників, вивчені стимули і мотиви діяльності працівників тощо.

Слід зазначити, що проблема дослідження особливостей мотивації персоналу шляхом управління конфліктами в процесі командної роботи залишається недостатньо вивченою.

Цілі статті. Метою статті $є$ розробка теоретичних положень та практичних рекомендацій щодо особливостей мотивації в процесі командної роботи в організації, визначенні напрямів мотивації ефективної командної роботи персоналу організації, зокрема шляхом управління конфліктами, удосконаленні форм і методів управління конфліктами шляхом посилення чи зменшення інтенсивності мотиваційних процесів та зменшення частки деструктивних конфліктів, що $є$ підгрунтям ефективного функціонування організації в цілому.

Виклад основного матеріалу дослідження 3 повним обгрунтуванням отриманих наукових результатів. Мотивація є рушійною силою існування та розвитку організації. Науковці визначають мотивацію як сукупність внутрішніх та зовнішніх рушійних сил, які у поєднанні спонукають працівників до певної діяльності, допомагають визначити його поведінку, виокремити необхідні форми цієї діяльності. Тобто, мотивація $є$ визначальним фактором результативності діяльності як окремих працівників, так і колективу в цілому. Така діяльність має визначену необхідну спрямованість, яка повинна орієнтуватись на досягнення як особистих цілей кожного 
працівника як члена команди, так і організаційних цілей [1, с. 39-43].

Мотивація може бути як матеріальною, так і нематеріальною. В сучасних умовах підвищується значення саме нематеріальної мотивації, тому що вона $є$ важливою складовою соціально-орієнтованого управління сучасною організацією. Таке управління $\epsilon$ важливою передумовою для задоволення потреб працівників, які все більше уваги приділяють саме соціалізації організації. Науковці виділяють наступні складові такого управління. [2, с. 70-77].

По-перше, це розвиток кожного працівника як особистості, який істотною мірою залежить від стану мікросоціального середовища. Це середовище, що оточує працівника як члена команди та формує його спосіб життя. До нього відносяться всі члени команди трудового колективу, вироблені у ньому норми, традиції, зразки поведінки, які $\epsilon$ важливими для функціонування групи.

По-друге, це соціальна установка працівника організації на трудову дисципліну та рівень його дисциплінованості;

По-третє, це достатній рівень мотивації, яка є поштовхом працівника та всієї команди до досягнення особистісних цілей та цілей підприємства одночасно завдяки задоволенню потреб обох сторін [3].

Тобто, механізм мотивації працівників сучасного підприємства повинен базуватися на основних положеннях соціально-орієнтованого менеджменту. До його головних принципів відносять наступні: сувора гуманістична орієнтація; корпоративне співтовариство; толерантність; співробітництво; висока відкритість; свобода; динамізм; відповідальність.

До цього треба додати, що соціально-орієнтований менеджмент грунтується на соціальних технологіях, які призначені для прийняття відповідних управлінських рішень соціального характеру, підвищення рівня ефективності організаційного проектування, підбору, навчання кадрів і розвитку персоналу (формування ефективної мотиваційної політики), зняття соціальної напруги в колективі.

3 метою запровадження основних положень соціально-орієнтованого менеджменту у повсякденну діяльність організацій доцільним є створення команд, які дозволяють оперативно реагувати на постійно виникаючі ринкові зміни в середовищі функціонування.

Команда є однією з рушійних сил, яка створюється в організації для виконання конкретного завдання чи реалізацію певного проекту. Така спільна співпраця та акумулювання досвіду людей дозволяє швидше та якісніше досягати поставлених загальних цілей [4].

Деякі науковці визначають команду як групу креативних людей, що згуртовані навколо одного лідера та виконують спільну справу із задоволенням, намагаються сполучати особисту та загальну мету, плідно та свідомо взаємодіють один з одним для їхнього досягнення, що в підсумку призводить до продуктивного результату їхньої справи-виробленню якісно нового товару або послуги [5].

Далі розглянемо основні принципи, які доцільно використовувати при створенні та формуванні команди [6].

- невелика кількість членів команди, бажано від 2 до 20 осіб, яка вважається оптимальною для ефективного управлінського процесу;

- підвищена складність поставленого завдання. Тобто, перед командою ставлять такий тип завдань, який звичайні групи виконавців не зможуть реалізувати.Створені команди акумулюють досвід окремих членів і в змозі добитися потрібних результатів;

- ретельний підбір учасників, які володіють взаємодоповнюючими знаннями, вміннями та навичками. При цьому потрібно враховувати психологічну сумісність членів команди, їхні вміння працювати разом, дослухатись та враховувати побажання і 
думки інших учасників, бути здатними на компроміси тощо. Окрім цього, члени команди повинні бути професіоналами, що готовні до різноманітних викликів, вміти ставити актуальну мету і розробляти стратегію іiі досягнення. Спираючись на вищезазначені знання, вміння і навички, учасники команди мають виконати поставлені завдання якнайкраще і в найкоротші терміни;

- довіра і співпраця в колективі команди. Тобто, це тісна співпраця та взаємопідтримка при вирішенні поставлених завдань та чесні, відкриті обговорення проблем, що виникають;

- спільна відповідальність за результат. Команда створюється задля досягнення спільної мети, тому і результат оцінюється лише після того, як кожний виконає свою ділянку роботи і сформулюється загальний висновок. Після отримання підсумкового результату, завдання вважається виконаним всією командою.

- спільна розробка загальної стратегії досягнення мети. Цей принцип спирається на розуміння командою результатів, які очікують від іiі створення. Для цього члени команди повинні самостійно запропонувати стратегію, що дозволить досягти намічених результатів; обговорити які види робіт доцільно здійснити задля досягнення мети, яким чином їх краще розподілити між окремими виконавцями. Також потрібно врахувати важливість встановлення часових меж та запропонувати ту чи іншу форму представлення отриманих результатів. При цьому важливим є пошук компромісів для успішного виконання завдання.

- відсутність різних видів протистоянь керівника та рядових членів команди. Потрібно враховувати ту обставину, що керівник і члени $є$ партнерами, які повинні плідно співпрацювати. При цьому керівник $\epsilon$ помічником, організатором та регулювальником дій рядових членів команди.

- індивідуальне «обличчя» кожної команди. Доведено, що команда з часом може мати певні елементи персоналізації. Вони можуть включати спільні риси поведінки їі членів, стиль одягу, характерні жарти чи фрази, спільні спогади;

- пошук компромісів при вирішенні конфліктів [6].

На цьому принципі зупинимось детальніше, тому що він безпосередно пов'язаний 3 темою нашого дослідження.Треба зазначити, що конфлікт $є$ однією 3 найбільш поширених форм організаційної взаємодії. Розвиток та нарощування потенціалу організації безпосередньо пов'язане із виникненням конфліктних ситуацій, які виникають при цьому. Разом 3 тим, конструктивні конфлікти є рушійним фактором розвитку організації.

В багатьох випадках, керівництво застосовує тактику уникнення конфліктних ситуацій в колективі будь-яким чином, оскільки в свідомості більшості працівників конфлікт призводить до погіршення взаємостосунків, втрати взаєморозуміння та довіри, зниженню працездатності тощо. Тому завданням керівництва можна вважати зосередження на запобіганні та професійному управлінні деструктивними конфліктами. Майстерність управління конфліктом заснована на глибоких знаннях керівником природи, ознак, технології та особливостей відповідного інструментарі [7, с.134-129].

Конструктивне управління конфліктами починається 3 ïx передбачення. Грамотний керівник повинен постійно працювати над виявленням та усуненням причин, що призводять до організаційних конфліктів. Спроби уникнути вирішення проблем призводить лише до їхнього поглиблення та погіршення соціально-психологічного клімату у колективі, що в підсумку може призвести до зниження продуктивності праці та кадрових втрат.

Існує багато ефективних методів управління конфліктами. 3 огляду на предмет нашого дослідження, ми вважаємо доцільним використання структурних методів, які включають заходи з профілактики і усунення організаційних конфліктів, що можуть 
виникати через нерівномірний розподіл повноважень, недостатній рівень організації праці, та головне, через недостатню систему мотивації [8]. У рамках вищезазначеного, можна застосовувати різні форми управління конфліктами всередині команди, зокрема раціонально організована система заохочень.

При цьому необхідно зазначити, що процес мотивації роботи команди має певні особливості, зокрема він передумовлює поєднання двох складових, тобто спонукання власних працівників до таких дій, які повинні поєднувати намагання досягти як загальних цілей організації, так i особистих. Важливим тут $є$ застосування таких стимулів, що є дієвими та дійсно важливими як винагородження кожного працівника в підсумку виконання окреслених завдань та сприяння досягненню визначених цілей. Таким чином, при поєднанні вищезазначеного, менеджер має змогу зформувати дієву систему стимулювання персоналу підприємства.

Ще однією особливістю мотивації в процесі командної взаємодії є створення сприятливої психологічної атмосфери. Це спирається на те, що сучасні працівники окрім матеріальної складової мотивації, все більше уваги приділяють психологічній. Кожний конкретний працівник є особистістю та має певну індивідуальну систему цінностей. Тобто, грамотний, ринково орієнтований менеджер, який розуміє важливість нематеріальної складової, буде намагатися створити таку соціально-психологічну атмосферу, яка сприятиме згуртуванню членів команди, підвищить їхній ступінь лояльності до організації. Лояльність працівників $\epsilon$ важливим чинником існування та конкурентоспроможності сучасної організації. Це пов'язано 3 тим, що позитивно налаштований, лояльний працівник $є$ однодумцем, який відчуває гордість за успіхи своєї організації, відчуває свою важливість, намагається якісно виконати доручену ділянку роботи [9, с.86-92].

Ще однією особливістю застосування принципів мотивації при командній взаємодії, є діагностика рівня задоволеності мотиваційних потреб. Це необхідно для того, щоб диференціювати особливості індивідуальних мотиваційних потреб кожного та знаходити конкретні, адаптовані під певного працівника, шляхи для покращення мотиваційного потенціалу. Аналізуючи ці шляхи, детально розглянувши рівень досягнення мотиваційних потреб кожного члена команди, менеджер має можливість дослідити та оцінити мотиваційний потенціал членів своєї команди, який є підгрунтям для виявлення мотиваційного потенціалу всієї команди та ступеня реалізації мотиваційних потреб.

Завдяки виявленому мотиваційному потенціалу керівництво повинно розробити та застосувати механізм його послідовного підвищення врахуючи тенденції розвитку мотиваційної спрямованості виконавців [10, с.56-160].

Висновки. Таким чином, дослідивши особливості мотивації персоналу в процесі командної роботи, зокрема шляхом управління конфліктами, можемо зробити висновки, що командна робота $є$ важливою складовою управлінського процесу, яка дозволяє покращити та виправити існуючі відхилення від бажаного стану у системі мотивації працівників організації.

Можна стверджувати, що цілі та наслідки тімбілдінгу є як передумовами попередження конфліктів в організації, так і методом управління ними. Розширення конфліктологічної грамотності передбачає іï наявність у керівників усіх рівнів організації та формування іiі у інших категорій персоналу. Щодо керівників, то вони мають володіти знаннями і перманентно їх розширювати відносно попередження, ідентифікації, стратегічного та тактичного управління конфліктами. При цьому вони мають володіти здатністю до ефективної рефлексії конфлікту, вміти інституалізувати його (визначати місце i формат вирішення конфлікту), легітимізувати конфлікт (визначити норми поведінки в організації, правил взаємодії в конфлікті, порядок та 
частоту комунікацій).

Важливим підсумком є можливість менеджера вчасно та ефективно реагувати на деякі відхилення, що можуть виникати в процесі командної роботи. Запобігти негативним наслідкам допоможуть розглянуті нами складові, такі як використання сучасних прогресивних методів мотивації, сприяння зформованості достатнього ступеня лояльності співробітників до підприємств та організацій. Це в підсумку дозволить використовувати дієвий механізм, який збільшить існуючий мотиваційний потенціал всіх співробітників.

\section{Список бібліографічного опису:}

1. Швець І. Б., Полиця А. М. Створення системи мотивації професійного розвитку персоналу підприємств. Bicник ОНУ ім. I.I. Мечникова. 2013. Т. 18. Вип. 3/3. С. 39-43.

2. Климчук В. О. Феномени розвитку внутрішньої мотивації Соціальна психологія. 2008. № 6 (32). С. 70-77.

3. Кудінова М. М., Мугдусієва Н. К., Чернишева А. С. Мотивація праці як інструмент соціальної політики. Ефективна економіка, № 4, 2017. URL: http://www.economy.nayka.com.ua/?op=1\&z=5543 (дата звернення: 25.10.2019).

4. Муха Р. А. Команда, iï сутність та особливості розвитку. Ефективна економіка.2015. №8. URL: http://www.economy.nayka.com.ua/?op=1\&z=4253

5. Голентовська О. С. Огляд зарубіжних та вітчизняних підходів до проблеми командотворення. Наука і освіта. №5. 2014. C. 24-30. URL:http://eprints.zu.edu.ua/13535/1/Holentovska_2014.pdf

6.Москаленко В.O. Сучасні підходи до формування команди проекту. URL: http://dspace.nuft.edu.ua/jspui/bitstream/123456789/20799/1/3.pdf

7. Криса О. Й. Формування сучасного підходу до ролі конфліктів в організації // Вісник Нац. ун-ту «Львівська політехніка». 2005. № 526. 684 с.

8. Новікова Н. Управління конфліктами в організації: підходи до вирішення та профілактики. Галицький економічний вісник. 2013. № 2(41). С.79-83.

9. Хоменко I. М., Грінько I. М. Використання методів мотивації праці в управлінні персоналом машинобудівних підприємств. Вісник Дніпропетровського університету. Серія «Економіка»: Вип. 4 (1). Дніпропетровськ: ДП «Видавництво ДНУ», 2010. Т. 18. С. 86- 92.

10. Петиченко А. Измените систему мотивации. Стандарты и качество. №1. М. 2007. С.56-60.

\section{References:}

1. Shvecj I. B., Polycja A. M. Stvorennja systemy motyvaciji profesijnogho rozvytku personalu pidpryjemstv. Visnyk ONU im. I.I. Mechnykova. 2013. T. 18. Vyp. 3/3. S. 39-43.

2. Klymchuk V. O. Fenomeny rozvytku vnutrishnjoji motyvaciji Socialjna psykhologhija. 2008. \# 6 (32). S. 70-77.

3. Kudinova M. M., Mughdusijeva N. K., Chernysheva A. S. Motyvacija praci jak instrument socialjnoji polityky. Efektyvna ekonomika, \# 4, 2017. URL: http://www.economy.nayka.com.ua/?op=1\&z=5543 (data zvernennja: 25.10.2019).

4. Mukha R. A. Komanda, jiji sutnistj ta osoblyvosti rozvytku. Efektyvna ekonomika.2015. \#8. URL: http://www.economy.nayka.com.ua/?op=1\&z=4253

5. Gholentovsjka O. S. Oghljad zarubizhnykh ta vitchyznjanykh pidkhodiv do problemy komandotvorennja. Nauka i osvita. \#5. 2014. S. 24-30. URL:http://eprints.zu.edu.ua/13535/1/Holentovska_2014.pdf

6. Moskalenko V.O. Cuchasni pidkhody do formuvannja komandy proektu. URL: http://dspace.nuft.edu.ua/jspui/bitstream/123456789/20799/1/3.pdf

7. Krysa O. J. Formuvannja suchasnogho pidkhodu do roli konfliktiv v orghanizaciji // Visnyk Nac. un-tu «Ljvivsjka politekhnika». 2005. \# 526. $684 \mathrm{~s}$.

8. Novikova N. Upravlinnja konfliktamy v orghanizaciji: pidkhody do vyrishennja ta profilaktyky. Ghalycjkyj ekonomichnyj visnyk. 2013. \# 2(41). S.79-83.

9. Khomenko I. M., Ghrinjko I. M. Vykorystannja metodiv motyvaciji praci v upravlinni personalom mashynobudivnykh pidpryjemstv. Visnyk Dnipropetrovsjkogho universytetu. Serija «Ekonomika»: Vyp. 4 (1). Dnipropetrovsjk: DP «Vydavnyctvo DNU», 2010. T. 18. S. 86- 92.

10. Petychenko A. Yzmenyte systemu motyvacyy. Standartы y kachestvo. \#1. M. 2007. S.56-60.

Дата подання публікації 19.10.2021p. 